\title{
HOLE DRILLING IN POLYMETHYL METHACRYLATE (PMMA) USING CO2 LASER
}

\author{
Rana M. Taha \\ Laser \& Optoelectronics Eng. Dep., Al-Nahrain University, Baghdad, Iraq \\ E-mail: Engrana.taha32@gmail.com \\ (Received: 22/5/2012; Accepted: 18/12/2012)
}

\begin{abstract}
Laser sources are used in a large variety of applications for material processing. It is mainly used for welding, cutting, drilling, laser annealing, etc. This study narrows the scope down to one of the process, namely, laser drilling.

The hole depth, width and penetration velocity of evaporation depend on different parameters such as power, material, exposure time, distance between drilling tool and the material, the drilling tool, etc. In this paper; the laser beam was used as drilling tool. $16 \mathrm{~W}$ $\mathrm{CO}_{2}$ laser $(10.6 \mu \mathrm{m})$ and transparent Perspex (PMMA) which is the abbreviation of polymethyl methacrylate work piece with $8 \mathrm{~mm}$ thickness were used. The distance between laser beam and the material was $5 \mathrm{~cm}$. Different powers for $\mathrm{CO}_{2}$ laser were used for different exposure time. Hole depth, time required for boiling, heat flow per unit area and penetration velocity of evaporation were calculated. Measured and calculated results were approximately the same. Many figures which representing the relations between laser power, time to reach boiling, hole width, hole depth and exposure time were obtained by using Matlab 2008 software program.
\end{abstract}

Keywords: Drilling PMMA, laser beam and heat flow.

\section{Introduction}

Drilling is a cutting process that uses a drill bit to cut or enlarge a hole in solid materials. The drill bit is a multipoint, end cutting tool. It cuts by applying pressure and rotation to the workpiece, which forms chips at the cutting edge.

Drilled holes are characterized by their sharp edge on the entrance side and the presence of burrs on the exit side (unless they have been removed). Also, the inside of the hole usually has helical feed marks [1].

Laser drilling is based on the absorption of the laser energy by the work piece and the 
conversion of photo energy into thermal energy. This thermal energy forms a large temperature gradient near the surface region of the work piece. When this temperature exceeds that of the melting and/ or vaporization temperature of the work piece, the work piece begins the ablate and a hole geometry is formed. With sufficient time, more material is removed and this hole geometry penetrates deeper into the work piece until the desired hole depth is achieved [2].

Drilling with solid state lasers is a thermal removal process. Due to the strong focused laser beam with high energy density, material is melted and evaporated. As a result of the evaporation and assist gas pressure, the material is thrown out of the hole.

One of the very first industrial uses of the laser was reported in 1965 when a diamond die was drilling using pulse ruby laser. A hole $4.7 \mathrm{~mm}$ in diameter $\& 2 \mathrm{~mm}$ deep was made in about 15 minutes; using a mechanical process this had previously taken 24 hours [3]. Zhang, Yao and Chen reports on experimental and numerical investigation of micromachining of copper using a frequency tripled Nd: YAG laser with 50 ns pulse duration [4]. LAZARE and TOKAREV investigated the micro drilling of polymers with ultraviolet laser beams. The mechanisms of the drilling process have been studied in details and an original analytical model has been constructed recently [5]. Collins and Gremaud presented a mathematical model of laser drilling. Assuming axi-symmetry of the process around the axis of the laser beam, a onedimensional formulation is obtained after cross-sectional averaging [6].

The energy required to remove material by melting is about $25 \%$ of that needed to vaporize the same volume, so a process that removes material by melting is generally favored. Whether melting or vaporization is more dominant in a laser drilling process depends on many factors, with laser pulse duration and energy playing an important role [7].

\section{2- Laser drilling}

The laser is actually an intense source of heat. The amount of heat energy absorbed by the work piece is very high which in turn generate high surface temperatures. This high surface temperature can be as high as the boiling point of the work piece. When the work piece reaches boiling point, the localized area starts to eject as gas or vapor from the surface and the surface recedes towards the work piece bulk. Over time, a hole with the required diameter and depth can be achieved [8].

Drilling is the normal area for YAG lasers but $\mathrm{CO}_{2}$ lasers can also be used on many of these applications. The advantage of the laser is that it can drill holes at an angle to the surface. It is fast and accurate; mechanical drilling is slow and causes extrusions at both ends 
of the hole which have to be cleaned [9].

Several advantages of using laser are: productivity, cost reducing and residual quality of cutting process are the main factors of laser technology over conventional cutting methods. The laser is also a noncontact tool; nothing touches the part being worked on and there are no saw blades or drill bits to break or keep clean. Other advantages in using laser are a small kerf width and high cut velocities combined with a small HAZ (Heat Affected Zone).Fig.1 shows cutting and drilling of materials using laser. [8]

\section{3- Theoretical calculations}

The rate of heat flow per unit area into the surface, is calculated by

$$
\mathrm{H}=\mathrm{I} *(1-\mathrm{R})
$$

I is the power intensity

$\mathrm{R}$ is the reflectivity

The time to reach surface boiling (vaporization) is calculated by

$$
\mathrm{t}_{\mathrm{b}}=(\pi / 4) *(\mathrm{~K} \rho \mathrm{C} / \mathrm{H} 2) *\left(\mathrm{~T}_{\mathrm{b}}\right)^{2}
$$

Where $\mathrm{K}$ is the thermal conductivity

$\rho$ is the density

$\mathrm{C}$ is the specific heat capacity

$\mathrm{T}_{\mathrm{b}}$ is the boiling point

$\mathrm{T}_{\mathrm{o}}$ calculate the maximum depth of penetration of the melting surface $(\mathrm{Zm})$, the following equation is used

$$
\operatorname{ierfc}\left(\mathrm{HZm} / \mathrm{K} \mathrm{T}_{\mathrm{b}} \sqrt{ } \pi\right)=\left(\mathrm{Tm} / \sqrt{ } \pi \mathrm{T}_{\mathrm{b}}\right)
$$

Where $\mathrm{H}$ is the rate of heat flow per unit area into the surface

$\mathrm{Zm}$ is the depth of melting

Tm is the melting point

And to calculate the penetration velocity of evaporation, the following equation is used [10].

$$
v_{\mathrm{s}}=\mathrm{H} / \rho\left(\mathrm{C} \mathrm{T} v+\mathrm{L}_{v}\right)
$$

Where $\mathrm{L}_{v}$ is the latent heat of vaporization.

\section{4- Experimental setup}

Figure (1) shows a setup for drilling PMMA using $16 \mathrm{~W} \mathrm{CO}_{2}$ laser (model DJG107$15 / 18$ ) working in continuous mode as a power source with efficiency 
(10-30)\%, laser beam diameter is $5 \mathrm{~mm}$, a power of 1, 2, 3 and $4 \mathrm{~W}$ were used. The distance between the laser beam and the PMMA sample is $5 \mathrm{~cm}$. PMMA thickness is $8 \mathrm{~mm}$. And the drilling process was implemented to drill holes with different time intervals.

Table (1) shows the parameters which were used to calculate the heat flow, time required for boiling, maximum depth of penetration of the melting surface and the penetration velocity of evaporation for PMMA work piece using equations (1), (2), (3) and (4) [11].

Table (2) shows the calculated parameters for drilling PMMA using $\mathrm{CO}_{2}$ laser, depending on the equations (1-4), the parameters listed in table (1) and laser parameters.

\section{5- Practical part and results}

Figures (2-5) show the holes in PMMA that drilled by $\mathrm{CO}_{2}$ laser, figure (2) shows the hole drilled by $1 \mathrm{~W}$ power and for exposure time of $70 \mathrm{sec}$, figure (3) shows the holes drilled by $2 \mathrm{~W}$ power and for exposure time of $46 \mathrm{sec}$, figure (4) shows the hole drilled by $3 \mathrm{~W}$ power and for exposure time of $37.5 \mathrm{sec}$ and figure (5) shows the hole drilled by $4 \mathrm{~W}$ power and for exposure time of $20.2 \mathrm{sec}$.

For the first drilling process (figure (2)), the hole depth was so small even if the exposure time was long; so it is clear in this figure that the laser beam can't evaporate a lot of layers of PMMA because it was been hit by $1 \mathrm{~W}$ laser power (maximum measured depth $=3 \mathrm{~mm}$ ), and for the other drilling processes (figures $(3,4 \& 5)$ ), the depths of holes were increased to $8 \mathrm{~mm}$ even if the exposure time was decreased because they were been hit by larger laser power so it could evaporate multi layers of PMMA and make deeper holes.

Figures (6-9) show the relations between measured and calculated parameters for PMMA, figure (6) illustrates that decreasing $\mathrm{H}$ increasing $\mathrm{t}_{\mathrm{b}}$, it is clear that $\mathrm{t}_{\mathrm{b}}$ is inversely proportional to the square value of $\mathrm{H}$ for both measured and calculated parameters, for decreasing $\mathrm{H}$ the values of $\mathrm{Z}_{\mathrm{m}}$ will increased in inversely proportional roughly linearly as shown in figure (7), the results are almost the same for both measured and calculated parameters. Figure (8) shows the relation between hole width and $\mathrm{H}$, and between hole depth and $\mathrm{H}$; this figure illustrates that increasing hole width from about $2.5 \mathrm{~mm}$ to $6 \mathrm{~mm}$ will increasing $\mathrm{H}$, this figure also illustrates that the hole depth is increased from $3 \mathrm{~mm}$ until $\mathrm{H}=9.37 * 10^{4} \mathrm{~W} / \mathrm{m}^{2}$ for $8 \mathrm{~mm}$ depth and then it fixed to this value for the other values of H. Figure (9) shows that the aspect ratio (hole depth divided by hole width) is proportional to the exposure time until it reaches $46 \mathrm{sec}$ then the aspect ratio began to decrease for increasing exposure time.

Also it appeared from these figures that the hole depth and penetration velocity of evaporation depend on laser power, exposure time, intensity, material density, specific heat capacity, boiling point and latent heat of vaporization as shown in equations $1,2,3 \& 4$. 


\section{6- Conclusion}

The following points can be concluded from this paper:

1- The aspect ratio depends on both laser power and exposure time.

2- The most suitable power for drilling a hole in a PMMA workpiece with $8 \mathrm{~mm}$ thickness using a $\mathrm{CO}_{2}$ laser working in $\mathrm{CW}$ mode was $2 \mathrm{~W}$ where in this value of power, a maximum value of the aspect ratio was achieved.

3- Hole depth remains constant (equal to the material thickness $8 \mathrm{~mm}$ ) after $9.37 * 10^{4}$ $\mathrm{W} / \mathrm{m}^{2}$ for different laser power and exposure time.

4- When the power was not sufficient to drill a hole even if the exposure time was increased; the heat was diffused inside the material and not along the depth.

5- The increasing in laser power leads to a significantly increasing in the diameter of the hole until it reaches to a certain value where the increasing in the diameter became slightly.

\section{7- References}

1. Bralla, James G., DESIGN FOR MANUFACTURABILITY HANDBOOK, New York: McGraw-Hill. p. 4-56, 1999.

2. Zhong Da Rong, Victor, "Numerical Modelling of Laser Drilling”, SIM University, 2008-2009.

3. William P. Walters and Steven B. Segletes, "An exact solution of the long rod penetration equations", International Journal of Impact Engineering, Volume 11, Issue 2, 1991, Pages 225-231.

4. W. Zhang, Y. L. Yao and K. Chen, " Modelling and Analysis of UV Laser Micromachining of Copper", the International Journal of Advanced Manufacturing Technology, Volume 18 (5), Springer Journals - Sep 1, 2001

5. Sylvain LAZARE and Vladimir TOKAREV," Recent Experimental and Theoretical Advances in Microdrilling of Polymers with Ultraviolet Laser Beams", Proceedings of SPIE Vol. 5662 (SPIE, Bellingham, WA, 2004) 221-231.

6. Jeb Collins and Pierre Germaud, "A simple model for laser drilling ", Journal of mathematics and Computers in simulation, volume 81 Issue8, April, 2011, Pages 1541-1552.

7. Basu, S. and T. DebRoy, "Liquid Metal Expulsion During Laser Irradiation." J. Appl. Phys., 72: p. 3317-3322, 1992. 
8. Jeff Hecht and Dick Teresi, 'Laser-Light of Million uses', General Publishing company Ltd, Canada 1998.

9. William M. Steen, “Laser Material Processing”, Springer-Verlag London Limited, p. 99, 1991.

10. J. Wilson, J.F.B. Hawkes, “Laser principles and applications”, 1988.

11. Physical properties of PMMA, Retrieved on 15/4/2005 from internet http://www.Hsinhwa.com

Table (1): PMMA parameters used in calculations.

\begin{tabular}{|c|c|}
\hline Parameters & PMMA \\
\hline Thermal Conductivity $(\mathrm{J} / \mathrm{ms} . \mathrm{K})$ & 0.19 \\
\hline Density $\left(\mathrm{Kg} / \mathrm{m}^{3}\right)$ & 1190 \\
\hline Heat capacity $(\mathrm{J} / \mathrm{Kg} . \mathrm{K})$ & 1466 \\
\hline Boiling Temperature $\left({ }^{\circ} \mathrm{C}\right)$ & 200 \\
\hline Melting Temperature $\left({ }^{\circ} \mathrm{C}\right)$ & 140 \\
\hline latent heat of vaporization $(\mathrm{J} / \mathrm{g})$ & 1620 \\
\hline Refractive index & 1.492 \\
\hline
\end{tabular}

Table (2): Calculated parameters for drilling PMMA by using $\mathrm{CO}_{2}$ laser.

\begin{tabular}{|c|c|c|c|c|}
\hline Power $(\mathrm{W})$ & $\mathrm{H}\left(\mathrm{W} / \mathrm{m}^{2}\right)$ & $\mathrm{t}_{\mathrm{b}}(\mathrm{sec})$ & $\mathrm{Zm}(\mathrm{mm})$ & $v_{\mathrm{s}}(\mathrm{m} / \mathrm{sec})$ \\
\hline 1 & $4.685^{*} 10^{4}$ & 4.74 & 0.2875 & $2.06^{*} 10^{-5}$ \\
\hline 2 & $9.37 * 10^{4}$ & 1.186 & 0.144 & $4.12^{*} 10^{-5}$ \\
\hline 3 & $14.05^{*} 10^{4}$ & 0.527 & 0.096 & $6.17 * 10^{-5}$ \\
\hline 4 & $18.74 * 10^{4}$ & 0.296 & 0.072 & $8.23 * 10^{-5}$ \\
\hline
\end{tabular}

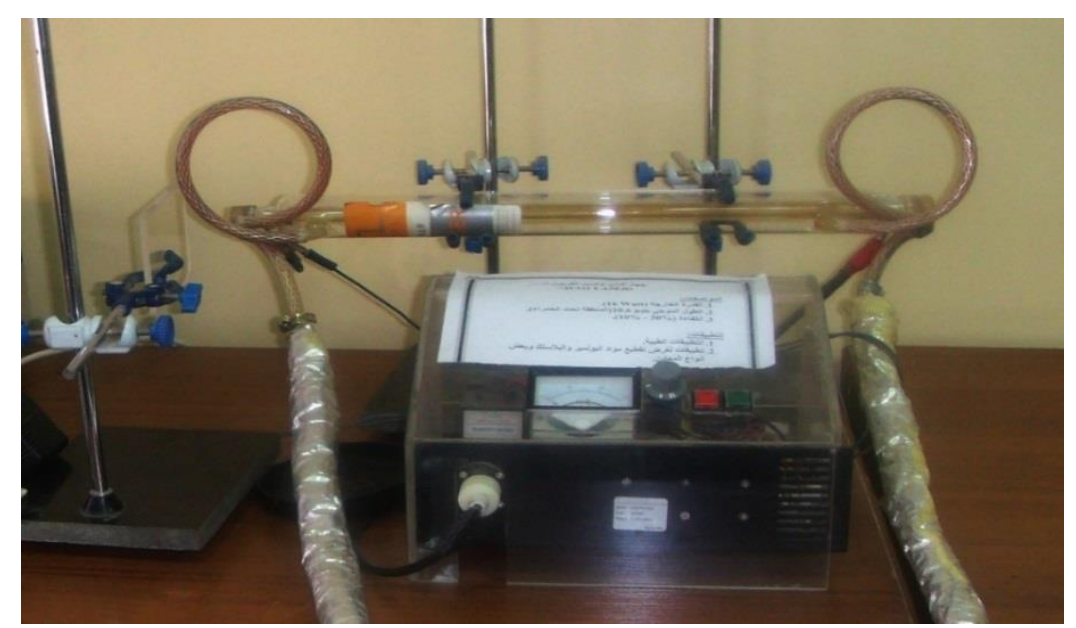

Figure (1): Setup used for PMMA drilling. 


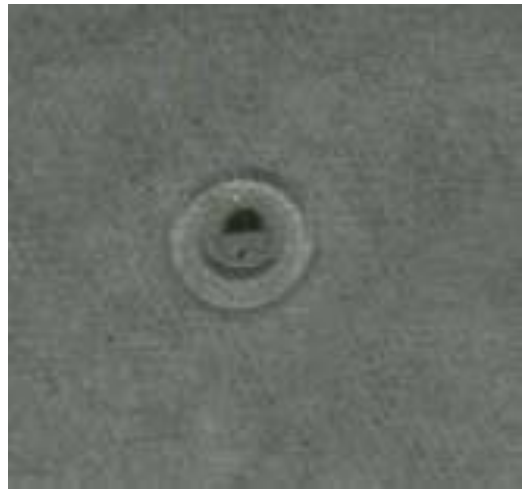

Figure (2): Hole with $\mathrm{P}=1 \mathrm{~W}$, ex. time $=70$.

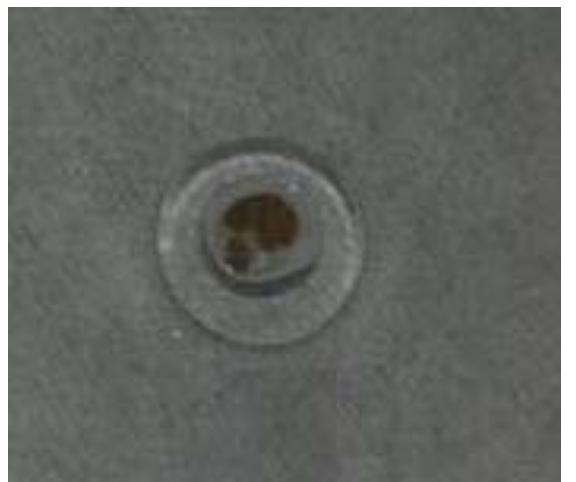

Figure (3): Hole with $\mathrm{P}=2 \mathrm{~W}$, ex. time $=46 \mathrm{sec}$

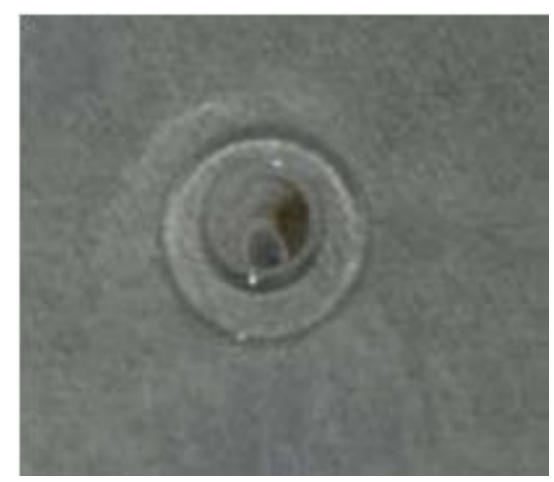

Figure (4): Hole with $\mathrm{P}=3 \mathrm{~W}$, ex. time $=37.5 \mathrm{sec}$

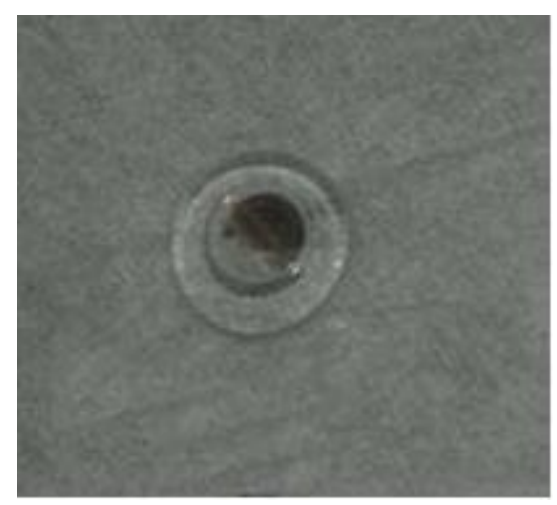

Figure (5): Hole with $\mathrm{P}=4 \mathrm{~W}$, ex. time=20.2 sec. 


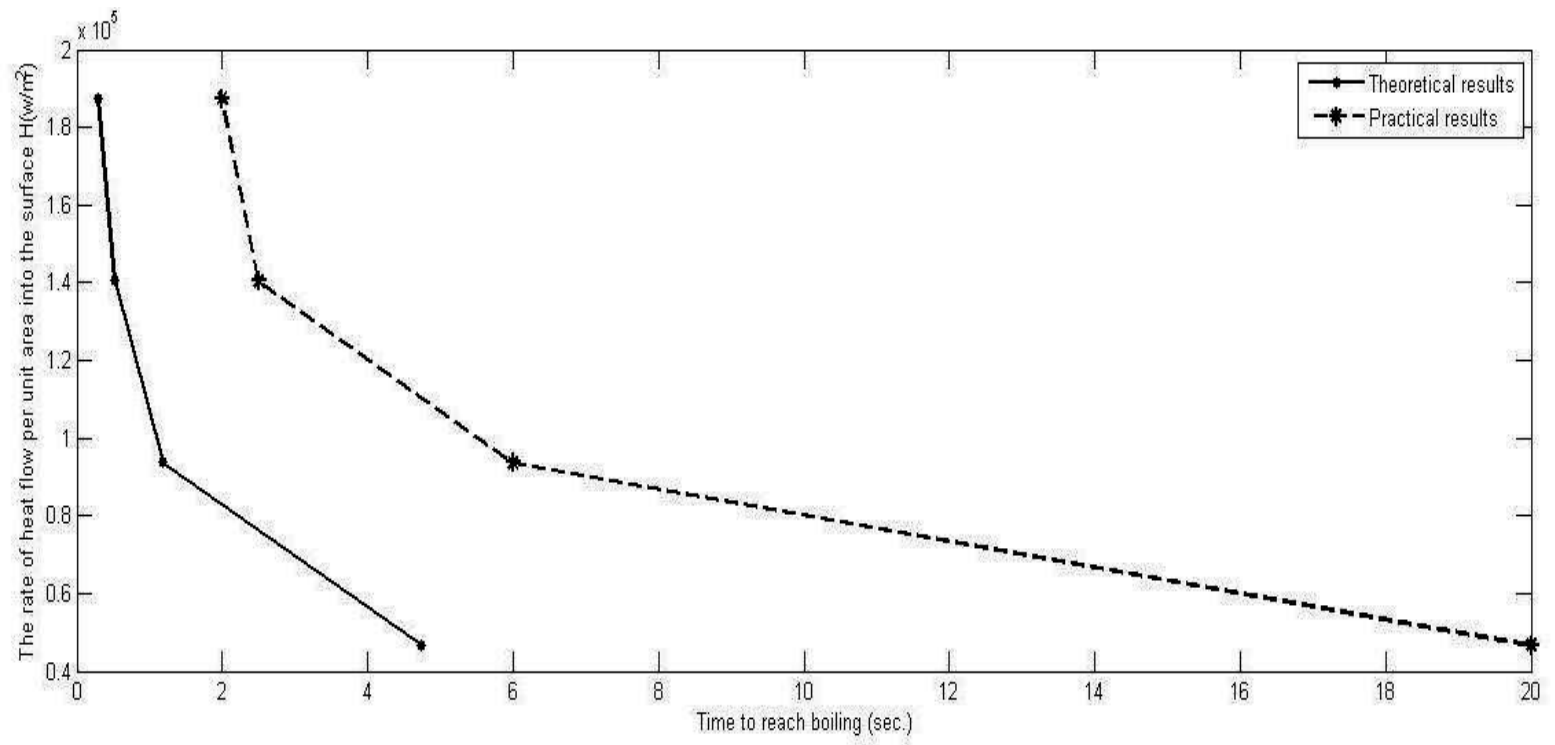

Figure (6): The relation between the rate of heat flow per unit area into the surface $\mathrm{H}\left(\mathrm{w} / \mathrm{m}^{2}\right)$ and the time to reach boiling $\mathrm{t}_{\mathrm{b}}(\mathrm{sec})$.

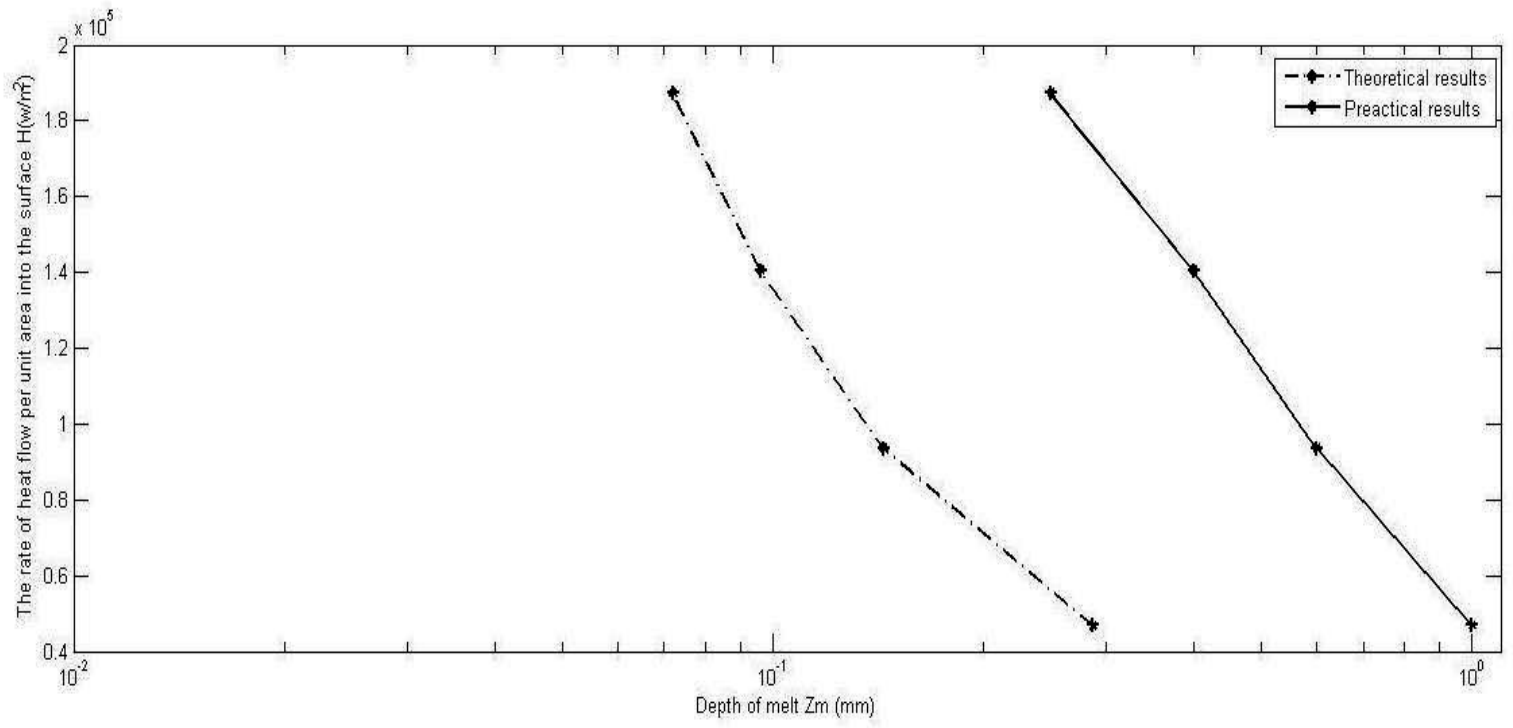

Figure (7): The relation between the rate of heat flow per unit area into the surface $\mathrm{H}\left(\mathrm{w} / \mathrm{m}^{2}\right)$ and the depth of melt $\mathrm{Zm}(\mathrm{mm})$. 


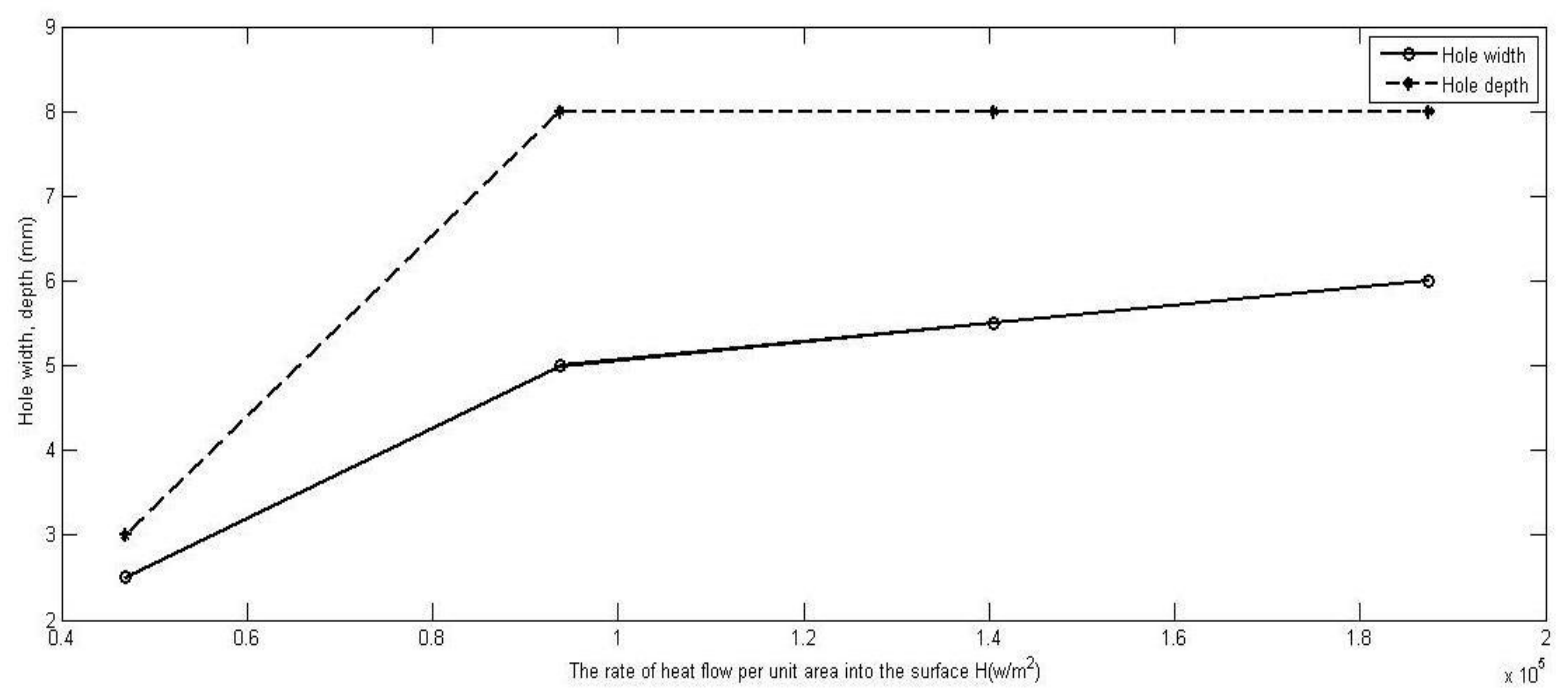

Figure (8): The relation between the rate of heat flow per unit area into the surface $\mathrm{H}\left(\mathrm{w} / \mathrm{m}^{2}\right)$

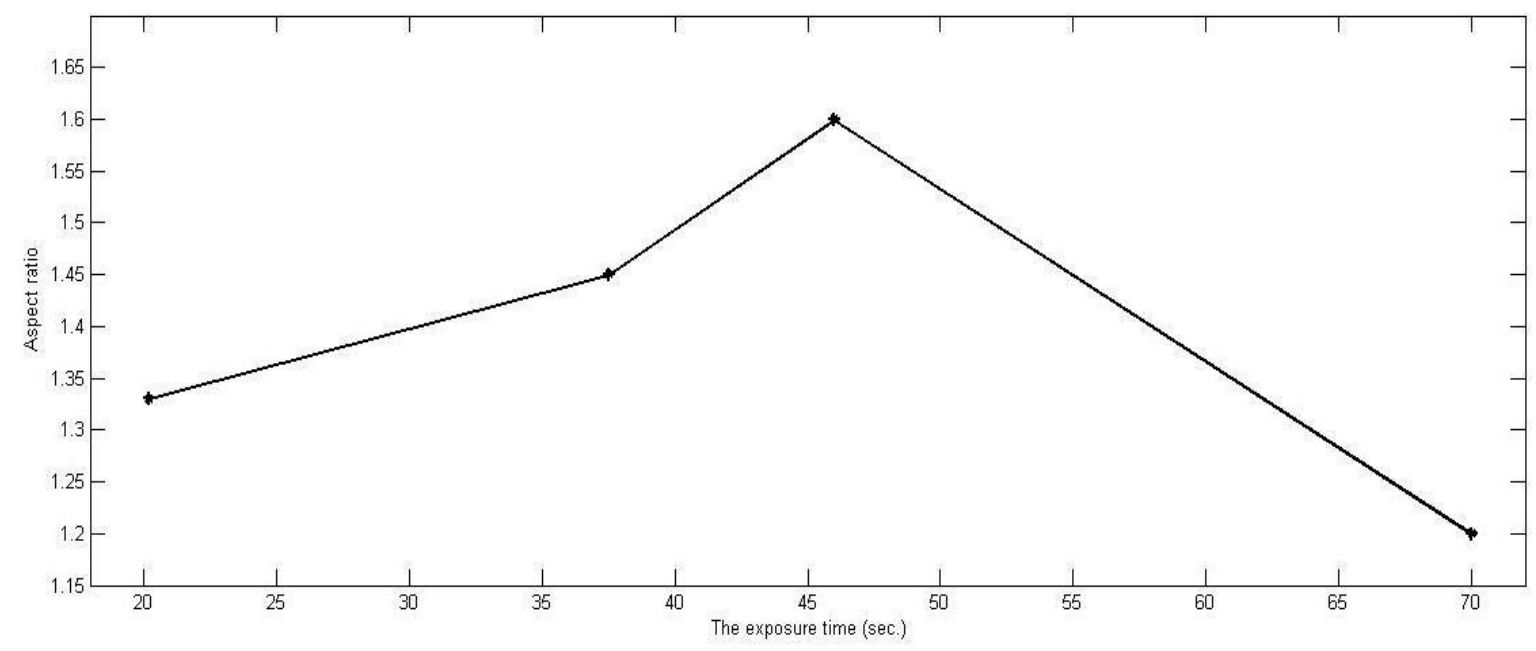

and the hole depth, width (mm).

Figure (9): The relation between the aspect ratio $A_{r}$ and the exposure time (sec). 


\title{
حفر ثقوب في مادة البيرسبكس باستخدام ليزر ثنائي اوكسيد الكاريون
}

\author{
رنا محمد طه
}

مدرس مساعد/ قسم هندسة الليزر والالكترونيات البصرية/ جامعة النهرين

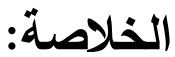

ان مصادر الليزر تستخدم في العديد من تطبيقات معالجة المواد وبصورة رئيسية في عمليات اللحام، القطع ،الحفر،

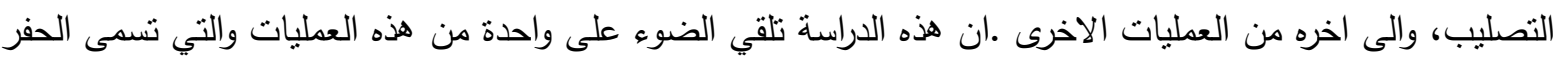
باستخدام الليزر •

عمق الحفرة, عرضها وسرعة عمق التبخير تعتمد على معاملات مختلفة مثل القدرة, المادة, زمن التعرض, المسافة بين اداة الحفر والمادة, اداة الحفر , الخ. في هذا البحث; شعاع الليزر سيستخدم كأداة حفر . W16 ليزر ثنائي اوكسبد

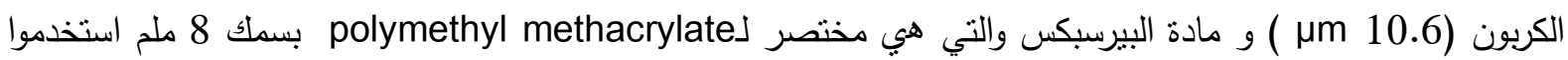
في هذا البحث. المسافة بين شعاع الليزر والمادة mm 5. نم استخدام قدرات ليزر مختلفة لزمن تعرض مختلف. تم

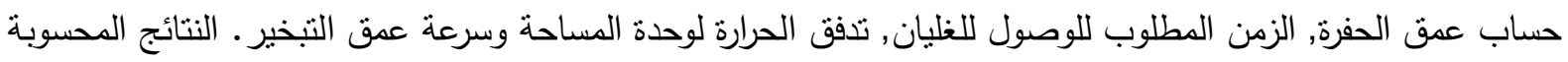
والمقاسة تقريباً متثابهة. تم استخدام برنامج 2008 Matlab للحصول على رسوم تمنل العلاقات بين قدرة الليزر , الزمن المطلوب للوصول للغليان, عرض الحفرة, عمق الحفرة وزمن التعرض. الكلمات المفتاحية: حفر بيرسبيكس (PMMA), شعاع الليزر وتدفق الحرارة. 